\title{
PERAMALAN CURAH HUJAN BULANAN DESA SUNGAI IPUH SOLOK SELATAN DENGAN MODEL AUTOREGRESSIVE INTEGRATED MOVING AVERAGE
}

\author{
ISWAHYULI, HAZMIRA YOZZA, DODI DEVIANTO \\ Jurusan Matematika, \\ Fakultas Matematika dan Ilmu Pengetahuan Alam, Universitas Andalas, \\ Kampus UNAND Limau Manis Padang, Indonesia. \\ email : iswahyuli24@gmail.com
}

\begin{abstract}
Abstrak. Curah hujan merupakan salah satu unsur cuaca dan iklim yang sangat penting dalam berbagai aspek kehidupan. Dengan memprediksi keadaan curah hujan dimasa yang akan datang, berbagai permasalahan yang dapat timbul dapat diantisipasi sejak awal. Curah hujan merupakan data deret waktu, oleh karena itu peramalan curah hujan dapat dilakukan dengan model Autoregressive Integrated Moving Average (ARIMA). Pada penelitian ini, peramaan dilakukan menggunakan data curah hujan bulanan Sungai Ipuh Solok Selatan dari Januari 2003 hingga Desember 2016. Model ARIMA terbaik yang diperoleh adalah $A R I M A(1,0,2)$. Hasil peramalan menunjukkan curah hujan Sungai Ipuh tahun 2017 dan 2018 diprediksi akan cenderung konstan dengan curah hujan terendah terjadi pada akhir tahun.
\end{abstract}

Kata Kunci: Curah Hujan, Peramalan, ARIMA

\section{Pendahuluan}

Curah hujan merupakan salah satu unsur penting dari cuaca dan iklim. Variasi curah hujan bergantung pada waktu dan tempat. Dengan demikian tiap daerah memiliki curah hujan berbeda yang juga dapat berubah atau tetap tiap waktunya.

Keadaan curah hujan suatu daerah dapat menentukan tipe vegetasi, jenis komoditas pertanian, teknik bercocok tanam, dan aspek-aspek sosial lainnya. Selain itu, curah hujan yang terlalu tinggi ataupun rendah dapat berakibat buruk pada lingkungan, curah hujan yang tinggi dapat menyebabkan banjir sedangkan curah hujan yang terlalu rendah dapat meningkatkan potensi keabakaran hutan dan lahan. Melihat hal ini maka diperlukan suatu analisa statistika untuk meramalkan keadaan curah hujan dimasa yang akan datang. Hasil peramalan curah hujan tersebut diharapkan dapat digunakan sebagai salah satu paremeter dalam menanggulangi masalah-masalah yang dapat timbul dimasa yang akan datang.

Data curah hujan adalah data deret waktu. Dengan mengidenifikasi pola dari data masa lalu, akan dilakkukan peramalan untuk memperoleh prediksi suhu udara di masa yang akan datang. Dalam penelitian ini, model peramalan yang digunakan adalah model Autoregressive Integrated Moving Average (ARIMA). 


\section{Tinjauan Pustaka}

\subsection{Curah Hujan}

Curah hujan merupakan ketebalan air hujan yang terkumpul pada luasan $1 \mathrm{~m}^{2}$. Curah hujan dihitung dengan satuan mm (milimeter), yaitu tinggi air yang tertampung pada area seluas $1 \mathrm{~m}^{2}$. Jadi curah hujan $1 \mathrm{~mm}$ adalah jumlah air yang turun dari langit sebanyak $0,001 \mathrm{~m}^{3}$ atau 1 liter [1].

\subsection{Seasonal Autoregressive Integrated Moving Average (ARIMA)}

Model Autoregressive Integrated Moving Average (ARIMA) adalah kombinasi model AR dan MA untuk data yang tidak stasioner. Secara umum, model ARIMA untuk deret waktu $X_{t}$ dinotasikan $\operatorname{ARIMA}(p, d, q)$ adalah [7]:

$$
\Phi_{p}(B)(1-B)^{d} X_{t}=\theta_{q}(B) \varepsilon_{t} .
$$

Data yang digunakan untuk pemodelan harus harus berada dalam keadaan stasioner terlebih dahulu. Data deret waktu dikatakan stasioner jika data tersebut memiliki nilai tengah dan ragam yang konstan sepanjang waktu pengamatan [2]. Data deret waktu yang tidak stasioner terhadap nilai tengah dapat distasionerkan dengan melakukan pembedaan (differencing). Pembedaan dinyatakan sebagai berikut:

$$
\nabla^{(d)} X_{t}=(1-B)^{d} X_{t}
$$

dimana $d$ adalah orde pembedaan dan B adalah operator shift mundur.

Stasioneritas data terhadap nilai tengah dapat dilihat menggunakan uji Augmented Dickey-Fuller (ADF)[7]. Hipotesis yang digunakan dalam uji ADF adalah:

$$
\begin{array}{ll}
H_{0}: \phi=1 & \text { (data tidak stasioner), } \\
H_{1}: \phi<1 & \text { (data stasioner). }
\end{array}
$$

Kriteria pengambilan keputusan adalah tolak $H_{0}$, jika statistik uji ADF lebih kecil dibandingkan nilai kritis tabel Dickey-Fuller.

Stasioneritas data terhadap ragam dapat dilihat menggunakan uji Box-Cox [7]. Transformasi Box-Cox dilakukan berdasarkan nilai rounded value $(\lambda)$ dari data yang akan di transformasi. Jika nilai $\lambda$ pada uji Box-Cox adalah 1 maka data telah stasioner terhadap ragam dan tidak diperlukan transformasi. Sebaliknya jika nilai $\lambda \neq 1$ maka perlu dilakukan transformasi hingga diperoleh nilai $\lambda=1$.

Setelah stasioneritas data terpenuhi, selanjutnya dilakukan identifikasi model untuk menentukan orde dari model $\operatorname{ARIMA}(p, d, q)$ dengan melihat fungsi autokorelasi dan fungsi autokorelasi parsial. Fungsi autokorelasi merupakan ukuran untuk menyatakan keeratan hubungan linier antara dua data deret waktu yang dipisahkan oleh lag (selisih waktu) tertentu dengan rumus umum [2]:

$$
\gamma_{h}=\operatorname{Cov}\left(X_{t+h}, X_{t}\right)=E\left[\left(X_{t}-\mu\right)\left(X_{t+h}-\mu\right)\right],
$$

dimana penduganya adalah $\widehat{\gamma}_{h}=\frac{1}{n} \Sigma_{t=1}^{n-h}\left[\left(X_{t}-\bar{X}\right)\left(X_{t+h}-\bar{X}\right)\right]$, sedangkan fungsi autokorelasi parsial pada lag $\mathrm{h}$, dinotasikan dengan $\Phi_{h h}$ adalah korelasi antara $X_{t}$ 
dan $X_{t+h}$ setelah ketergantungan linier antara $X_{t+1}, X_{t+2}, \cdots, X_{t+h-1}$ dihilangkan dengan rumus umum [7]:

$$
\gamma_{h}=\operatorname{Corr}\left(X_{t+h}, X_{t}\right)=\frac{\gamma_{h}}{\gamma_{0}}
$$

dimana penduganya adalah

$$
\widehat{\rho}_{h}=\frac{\widehat{\gamma_{h}}}{\widehat{\gamma_{0}}}=\frac{\frac{1}{n} \Sigma_{t=1}^{n-h}\left[\left(X_{t}-\bar{X}\right)\left(X_{t+h}-\bar{X}\right)\right]}{\frac{1}{n} \Sigma_{t=1}^{n}\left[\left(X_{t}-\bar{X}\right)^{2}\right]} .
$$

Setelah identifikasi model, selanjutnya dibentuk model-model yang mungkin dapat digunakan dan dipilih model yang signifikan dengan melakukan uji signifikansi parameter dengan hipotesis sebagai berikut [7]:

$$
\begin{aligned}
& H_{0}: \phi=0 \text { atau } \theta=0, \\
& H_{1}: \phi \neq 0 \text { atau } \theta \neq 0,
\end{aligned}
$$

dengan statistik uji yang digunakan adalah:

$$
t=\frac{\widehat{\Phi}}{S E(\widehat{\Phi})} \text { atau } t=\frac{\widehat{\theta}}{S E(\widehat{\theta})},
$$

dimana $n$ adalah banyaknya pengamatan.

Kriteria tolak $H_{0}$ atau parameter signifikan jika $\left|t_{h i t}\right|>t_{/ 2, d f}$ dengan derajat bebas $d f=n-1$ atau $p$-value $<\alpha$.

Model-model yang signifikan di evaluasi untuk mendapatkan model terbaik dengan melihat nilai Akaike Information Criterion (AIC) dan Schwartz Criterion (SC). Rumus umum AIC dan SC adalah [7]:

$$
\begin{aligned}
A I C(M) & =n \ln \Sigma_{t=1}^{n} e_{t}^{2}+2 M, \\
S C & =n \ln \Sigma_{t=1}^{n} e_{t}^{2}+M \ln (M),
\end{aligned}
$$

dimana $\sum_{t=1}^{n} e_{t}^{2}$ adalah jumlah kuadrat residu, $n$ banyaknya pengamatan, dan $M$ jumlah parameter model. Model terbaik adalah model dengan nilai AIC dan SC terkecil [7].

Sebelum melakukan peramalan, model terbaik yang diperoleh didiagnosa apakah telah layak digunakan untuk peramalan dengan melakukan uji terhadap residu model. Model dikatakan layak digunakan bila residu model bersifat white noise, berdistribusi normal, dan tidak heteroskedastisitas. Residu model bersifat white noise berarti tidak terjadi autokorelasi pada residu, sehingga untuk melihat apakah residu bersifat white noise dapat dilakukan uji autokorelasi yaitu dengan menggunakan uji L-JungBox dengan hipotesis:

$$
\begin{array}{ll}
H_{0}: \rho_{h}=0 & \text { (tidak terjadi autokorelasi), } \\
H_{1}: \rho_{h} \neq 0 & \text { (terjadi autokorelasi), }
\end{array}
$$

dengan statistik uji yang digunakan adalah:

$$
Q_{L B}=n(n+2) \Sigma_{h=1}^{K}\left(\frac{{\widehat{\rho_{h}}}^{2}}{n-h}\right),
$$


dimana $\widehat{\rho_{h}}$ adalah koefisien autokorelasi residu pada lagh $=1,2, \cdots, K, K$ adalah lag maksimum.

$H_{0}$ akan ditolak jika nilai $Q_{L B}>\chi_{\alpha}^{2}(K-p-q)$ atau $p$-value $<\alpha$ [4].

Normalitas residu dapat dilihat dengan melakukan uji Jarque Berra, dimana hipotesis yang digunakan adalah:

$$
\begin{aligned}
& H_{0} \text { : residu tidak berdistribusi normal, } \\
& H_{1} \text { : residu berdistribusi normal. }
\end{aligned}
$$

dengan statistik uji yang digunakan adalah:

$$
J B=n\left(\frac{S^{2}}{6}+\frac{(K-3)^{2}}{24}\right) \sim \chi_{2}^{2},
$$

dimana $n$ adalah ukuran contoh, $S$ skewness, dan $K$ kurtosis. Dengan taraf signifikan $\alpha=5 \%, H_{0}$ akan ditolak jika nilai Jarque Berra $>\chi_{\alpha}^{2}(2)$ [3].

Heteroskedastisitas pada residu dapat dilihat dengan uji white, dimana hipotesis yang digunakan adalah:

$$
\begin{aligned}
& H_{0} \text { : residu tidak heteroskedastisitas, } \\
& H_{1} \text { : residu heteroskedastisitas, }
\end{aligned}
$$

dengan statistik uji:

$$
W=n R^{2}
$$

dimana $n$ adalah ukuran contoh dan $R^{2}$ adalah koefisien determinasi. Pada taraf signifikan $\alpha=5 \%$, jika probabilitas white $\left(O b s * R^{2}\right)<\alpha$, maka tolak $H_{0}$ atau terjadi gejala heteroskedastisitas pada residu [6].

\section{Pembahasan}

\subsection{Identifikasi Data}

Identifikasi data dilakukan untuk melihat dan memeriksa tipe data yang akan diolah. Pemeriksaan ini dapat dilakukan dengan melihat plot data dan korelogram data asli rata-rata curah hujan bulanan Sungai Ipuh.

Plot data asli pada Gambar 1 menunjukkan data curah hujan desa Sungai Ipuh mengalami fluktuasi naik turun. Korelogram data asli menunjukkan fluktuasi yang terjadi pada data curah hujan Sungai Ipuh tidak menunjukkan pola berulang. Dengan demikian, dapat disimpulkan data curah hujan bulanan Sungai Ipuh tidak mengandung pola musiman sehingga untuk melakukan peramalan pada penelitian ini dapat digunakan model ARIMA biasa.

\subsection{Pemodelan ARIMA $(p, d, q)$}

Data yang akan dianalisis harus berada dalam keadaan stasioner terhadap nilai tengah dan ragam terlebih dahulu. Dengan menggunakan uji Box-cox pada data asli, diperoleh nilai Round Value $(\lambda)=0.50$, sehingga diperlukan transformasi $\sqrt{X_{t}}$ untuk menstasionerkan data terhadap ragam. Selanjutnya diperiksa apakah data 


\begin{tabular}{|c|c|c|c|c|c|c|}
\hline Autocorrelation & Partial Correlation & & $A C$ & PAC & Q-Stat & Prob \\
\hline 䛲 & 吅 & 1 & 0.364 & 0.364 & 22.629 & 0.000 \\
\hline 味 & 19 & 2 & 0.213 & 0.093 & 30.450 & 0.000 \\
\hline 追 & $1 \sqrt{11}$ & 3 & 0.153 & 0.056 & 34.486 & 0.000 \\
\hline ifi & ci & & -0.029 & -0.134 & 34.634 & 0.000 \\
\hline id, & i) & & -0.036 & -0.014 & 34.858 & 0.000 \\
\hline if, & 1. & & $\begin{array}{r}-0.029 \\
-0.029\end{array}$ & 0.003 & $\begin{array}{r}35.010 \\
35.010\end{array}$ & 0.000 \\
\hline in & in, & 7. & $\begin{array}{l}-0.029 \\
-0.084\end{array}$ & -0.055 & 36.274 & 0.000 \\
\hline in, & 11, & 8. & -0.038 & 0.012 & 36.525 & 0.000 \\
\hline id, & id 1 & 9. & .0 .065 & -0.050 & 37.277 & 0.000 \\
\hline i" & ifi & 10 & 0.004 & 0.064 & 37.280 & 0.000 \\
\hline ifi & ifi, & 11 & 0.053 & 0.044 & 37.785 & 0.000 \\
\hline 尚 & in & 12 & 0.159 & 0.152 & 42.438 & 0.000 \\
\hline , & c. & 13 & 0.035 & -0.110 & 42.670 & 0.000 \\
\hline 11, & it) & 14 & -0.009 & -0.054 & 42.685 & 0.000 \\
\hline 10. 1 & $c_{1}$ & 15 & -0.097 & -0.120 & 44.435 & 0.000 \\
\hline d. & 1). & 16 & -0.114 & -0.012 & 46.868 & 0.000 \\
\hline 14, & ili, & 17 & .0 .098 & -0.012 & 48.673 & 0.000 \\
\hline ig, & ifi, & 18 & -0.081 & -0.009 & $\begin{array}{l}49.921 \\
4.973\end{array}$ & 0.000 \\
\hline c, & id, & 19 & $\begin{array}{r}-0.119 \\
-.087\end{array}$ & $\begin{array}{l}-0.073 \\
-0.073\end{array}$ & 52.653 & 0.000 \\
\hline , & id, & & -0.098 & -0.045 & 54.520 & 0.000 \\
\hline ; & id & 21. & -0.125 & -0.056 & 57.552 & 0.000 \\
\hline 10, & ifi & 22. & -0.087 & -0.030 & 59.026 & 0.000 \\
\hline .1, & 1,1 & 23 . & -0.011 & 0.034 & 59.051 & 0.000 \\
\hline ib & $b_{1}$ & 24 & 0.085 & 0.071 & 60.492 & 0.000 \\
\hline 5 & 16 & 25 & 0.082 & 0.038 & 61.841 & 0.000 \\
\hline ib & 16 & 26 & 0.131 & 0.079 & 65.284 & 0.000 \\
\hline (19 & 1,11 & 27 & 0.090 & 0.029 & 66.926 & 0.000 \\
\hline 151 & 1,1 & 28 & 0.081 & 0.028 & 68.258 & 0.000 \\
\hline 16, & $1 \sqrt{1}$ & 29 & 0.047 & -0.020 & 68714 & 0.000 \\
\hline , & ili & 30 & 0.021 & -0.014 & $\begin{array}{l}68.806 \\
\end{array}$ & 0.000 \\
\hline 161 & $1 b_{1}$ & 31 & 0.054 & 0.078 & 69.417 & 0.000 \\
\hline , & 111 & 32. & -0.001 & -0.024 & 69.417 & 0.000 \\
\hline ifi & ifi & & -0.047 & -0.020 & 69.888 & 0.000 \\
\hline ifi & i & & 0.029 & 0.046 & 70.064 & 0.00 \\
\hline$i_{1}$ & 16 & 35 & 0.071 & 0.070 & 71.134 & 0.00 \\
\hline ib & 16 & 36 & 0.126 & 0.047 & 74.570 & 0.000 \\
\hline
\end{tabular}

Gambar 1. Korelogram Data Asli

telah stasioner terhadap nilai tengah dengan melakukan uji ADF pada data transformasi. Hasil uji ADF diperoleh nilai ADF sebesar -8.760329 dengan nilai kritis tabel pada $\alpha=5 \%$ adalah -2.878723 . Karena nilai ADF lebih kecil dari nilai kritis tabel, maka dapat disimpulkan bahwa data telah stasioner terhadap nilai tengah.

Setelah data stasioner terhadap ragam dan nilai tengah, selajutnya dapat dilakukan identifikasi model untuk melihat orde dari model $\operatorname{ARIMA}(p, d, q)$ berdasarkan korelogram ACF dan PACF.

Korelogram PACF data stasioner pada Gambar 2 menunjukkan terjadi cut-off setelah lag 1, maka diduga orde model AR yaitu $p$ adalah 1 atau AR(1). Pada korelogram ACF terjadi cut-off setelah lag 3 sehingga diduga orde model MA yaitu $q$ adalah 3 atau MA(3). Karena data stasioner tanpa dilakukan differencing, maka orde $d$ dari model adalah 0, sehingga diduga model awal yang diperoleh adalah $\operatorname{ARIMA}(1,0,3)$.

Berdasarkan model awal yang diperoleh yaitu $A R I M A(1,0,3)$ dibentuk semua kemungkinan model yang dapat digunakan, selanjutnya dilakukan uji signifikan parameter untuk semua kemungkinan model tersebut. Model yang digunakan untuk peramalan adalah model dengan semua parameternya signifikan, dimana parameter dikatakan signifikan jika nilai p-value pada uji t $<\alpha=0.05$. Hasil uji signifikan parameter diperoleh model yang signifikan adalah model $A R I M A(0,0,1), A R I M A(0,0,2), A R I M A(0,0,3), A R I M A(1,0,0)$, $A R I M A(1,0,1)$, dan model $A R I M A(1,0,2)$.

Setelah diperoleh model-model yang signifikan dari semua kemungkinan model yang diduga, maka selanjutnya dilakukan evaluasi model untuk memperoleh model yang terbaik. Evaluasi model dilihat dari nilai Akaike info criterion (AIC) dan 


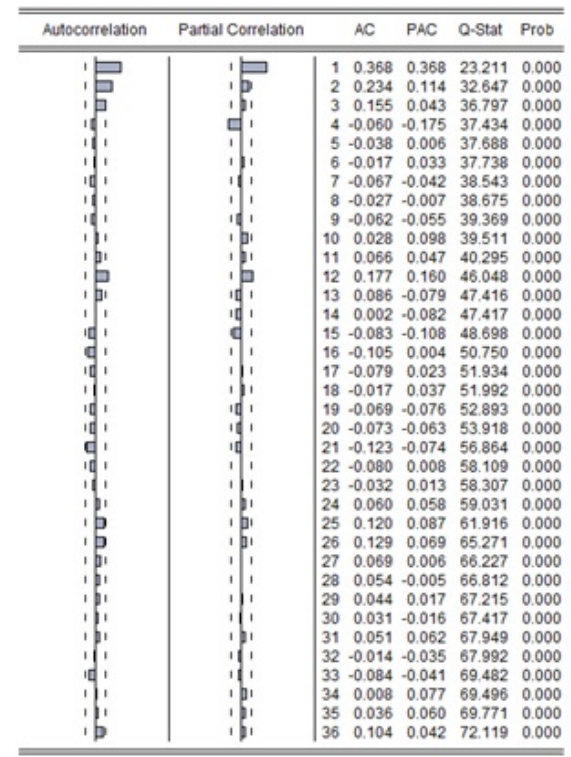

Gambar 2. Korelogram Data Stasioner

Schwarz criterion (SC), dimana model yang terbaik adalah model dengan nilai AIC dan SC terkecil. Dengan melakukan pengurutan pada nilai AIC dan SC dari nilai terkecil hingga terbesar serta dihitung rata-rata dari kedua urutan, selanjutnya rata-rata tersebut diurutkan kembali sehingga diperoleh model terbaik adalah model $\operatorname{ARIMA}(1,0,2)$ dengan persamaan:

$$
\left(1-\phi_{1} B\right) X_{t}=\left(1-\theta_{1} B-\theta_{2} B^{2}\right) \varepsilon_{t} .
$$

Setelah diperoleh model terbaik, dilakukan diagnosa model untuk melihat apakah model terbaik yang diperoleh layak digunakan untuk peramalan. Model dikatakan layak diguakan jika residu model bersifat white noise, berdistribusi normal, dan tidak heteroskedastisitas.

Untuk memeriksa apakah residu model bersifat white noise dapat dilihat dengan uji autokorelasi. Residu bersifat white noise jika tidak terjadi autokorelasi. Uji autokorelasi dapat dilakukan dengan uji Q-Ljung Box, Nilai uji Q-Ljung Box dapat dilihat dari nilai probabilitas $Q$-stat pada korelogram residu model. Bila nilai probabilitas $Q$-stat kurang dari $\alpha=0,05$ maka terjadi autokorelasi.

Korelogram residu model terbaik menunjukkan semua nilai probabilitas $Q$-stat lebih dari $\alpha=0,05$, sehingga dapat disimpulkan tidak terjadi autokorelasi pada residu. Dengan demikian dapat disimpulkan residu model bersifat white noise.

Melihat apakah residu berdistribusi normal dapat dilakukan dengan uji Jarque Berra (JB). Residu model dikatakan berdistribusi normal, jika nilai Jarque Berra $>\chi_{\alpha}^{2}(2)$. Berdasarkan tabel sebaran Chi-Square diperoleh nilai ${ }_{0}, 05^{2}(2)$ sebesar 5,991. Histogram normalitas residu menunjukkan nilai Jarque Berra sebesar 1,099608. Karena nilai Jarque Berra $>\chi_{0}, 05^{2}(2)$ maka dapat disimpulkan residu model berdistribusi normal. 
Heteroskedastisitas dari residu dapat dilihat dengan melakukan uji White. Residu model tidak heteroskedastisitas jika pada taraf signifikan $\alpha=5 \%$, nilai probabilitas White $\left(\mathrm{Obs} * R^{2}\right)>\alpha$. Berdasarkan hasil uji White, diperoleh nilai statistik uji White $\left(O b s * R^{2}\right)$ adalah 4.629787 dengan probabilitas sebesar 0.5921. Karena nilai probabilitas White $\left(O b s * R^{2}\right)>\alpha=5 \%$, maka dapat disimpulkan bahwa residu model tidak heteroskedastisitas.

Dengan demikian, berdasarkan hasil dari ketiga uji yang telah dilakukan dapat disimpulkan bahwa model $A R I M A(1,0,2)$ layak digunakan untuk peramalan.

\subsection{Peramalan}

Setelah model terbaik yang diperoleh yaitu model $A R I M A(1,0,2)$ memenuhi semua asumsi pada uji diagnostik model, maka selanjutnya dilakukan peramalan dengan model tersebut. Peramalan dilakukan menggunakan data hasil transformasi $\sqrt{X_{t}}$. Setelah diperoleh nilai peramalan, nilai tersebut ditransformasi kembali pada skala data asli. Berikut hasil peramalan rata-rata curah hujan bulanan Sungai Ipuh untuk periode Januari 2017 hingga Desember 2018.

\begin{tabular}{|l|r|}
\hline Jan 2017 & 5.359536 \\
\hline Feb 2017 & 5.358541 \\
\hline Mar 2017 & 5.357546 \\
\hline Apr 2017 & 5.356551 \\
\hline Mei 2017 & 5.355556 \\
\hline Jun 2017 & 5.354562 \\
\hline Jul 2017 & 5.353568 \\
\hline Ags 2017 & 5.352574 \\
\hline Sep 2017 & 5.35158 \\
\hline Okt 2017 & 5.350586 \\
\hline Nov 2017 & 5.349593 \\
\hline Des 2017 & 5.348599 \\
\hline Jan 2018 & 5.347606 \\
\hline Feb 2018 & 5.346613 \\
\hline Mar 2018 & 5.345621 \\
\hline Apr 2018 & 5.344628 \\
\hline Mei 2018 & 5.343636 \\
\hline Jun 2018 & 5.342643 \\
\hline Jul 2018 & 5.341651 \\
\hline Ags 2018 & 5.34066 \\
\hline Sep 2018 & 5.339668 \\
\hline Okt 2018 & 5.338677 \\
\hline Nov 2018 & 5.337685 \\
\hline Des 2018 & 5.336694 \\
\hline
\end{tabular}

Gambar 3. Data hasil peramalan dengan model $A R I M A(1,0,2)$

Berdasarkan Gambar 3, diprediksi bahwa rata-rata curah hujan bulanan Sungai Ipuh pada tahun 2017 dan 2018 cenderung konstan dengan curah hujan terendah terjadi pada bulan Desember. Berdasarkan data prediksi yang telah diperoleh, dapat diperkirakan bahwa penurunan curah hujan di Sungai Ipuh terjadi pada akhir tahun. Dengan adanya prediksi ini, dapat dilakukan strategi-strategi untuk menghadapi masalah yang dapat timbul kedepannya ataupun melakukan persiapan dalam bidang pertanian dan lainnya. 


\section{Kesimpulan}

Berdasarkan pengolahan data rata-rata curah hujan bulanan Desa Sungai Ipuh Solok Selatan dengan model ARIMA(p,d,q), diperoleh:

(1) Model ARIMA terbaik untuk peramalan rata-rata curah hujan bulanan Sungai Ipuh Solok Selatan adalah ARIMA $(1,0,2)$ dengan persamaan:

$$
X_{t}=0.999907 X_{t-1}+\varepsilon_{t}+0.686615 \varepsilon_{t-1}+0.303835 \varepsilon_{t-2} .
$$

(2) Berdasarkan model terbaik yang diperoleh, diprediksi bahwa rata-rata curah hujan bulanan Sungai Ipuh Solok Selatan pada tahun 2017 dan 2018 akan cenderung konstan dengan curah hujan terendah terjadi pada akhir tahun

\section{Daftar Pustaka}

[1] BMKG. 2017. FAQ BMKG Penjelasan Data Hujan. http://dataonline.bmkg.go.id/webfaq, tanggal akses 28 November 2017

[2] Brockwell, P.J. dan Davis, R.A. 1996. Introduction to Time Series and Forecasting. Springer Verlag, New York

[3] Gujarati, Damodar. 2004. Basic Econometrics. Fourth Edition. The McGrawHill Companies, New York

[4] Montgomery, D.C. dan Jennings, C.L. 2008. Introduction to Time Series Analysis and Forecasting. John Wiley And Son, Inc, New York

[5] Nurdin, D. 2017. Sebagian Besar Wilayah Provinsi Jambi Sudah Memasuki Musim Kemarau. http://www.tribunnews.com/regional/2017/06/09/sebagianbesar-wilayah-provinsi-jambi-sudah-memasuki-musim-kemarau, tanggal akses 28 Desember 2017

[6] Rosadi, D. 2012. Ekonometrika dan Analisis Runtun Waktu Terapan dengan Eviews. Andi Offset, Yogyakarta

[7] Wei, William W.S. 2006. Time Series Analysis: Univariate and Multivariate Methods. Second Edition. Pearson Education, United States 